\title{
Meta-Analysis the Effectiveness of Isometric Relaxation and Laser Therapy in Reducing Myofascial Pain Syndrome on Musculus Upper Trapezius
}

\author{
Alifiya Zulfa Indana1), Setyo Sri Rahardjo²), Hanung Prasetya3) \\ 1)Masters Program in Public Health, Universitas Sebelas Maret \\ 2) Faculty of Medicine, Universitas Sebelas Maret \\ 3)Study Program of Acupuntur, Health Polytechnics, Ministry of Health Surakarta
}

\section{ABSTRACT}

Background: Myofascial pain syndrome upper trapezius is a condition of neck pain caused by excessive muscle loading and can occur due to continuous activities with poor posture and ergonomics. There are many interventions that can be given to treat this MPS, such as Post isometric relaxation and laser therapy. This study aims to analyze the effect of post-isometric relaxation and laser therapy on pain reduction in cases of upper trapezius myofascial pain syndrome.

Subjects and Method: This study is a systematic review and meta-analysis conducted with PRISMA flow diagrams. Search articles through journal databases including: PubMed, Science Direct, Google Schoolar and PEDro by selecting articles published in 2010-2020. The keywords used were ("MPS Upper Trapezius" OR "Myofascial pain syndrome upper trapezius") AND ("PIR" OR "Post isometric relaxation") AND ("Laser" OR "Laser therapy") AND "randomized controlled trial". The inclusion criteria were full paper articles with Randomized Controlled Trial (RCT) research methods, the size of the relationship used was Mean SD, the interventions given were PIR and Laser therapy, the research subjects had an age range of 18-65 years, and had upper Myofascial pain syndrome. trapezius. Eligible articles were analyzed using the Revman 5.3 app.

Results: Meta-analysis of 16 articles showed that post isometric relaxation and laser therapy were able to reduce pain in cases of upper trapezius Myofascial pain syndrome. However, statistically insignificant PIR (SMD 0.18; 95\% $\mathrm{CI}=-0.36$ to $0.72 ; \mathrm{p}=0.51)$ and Laser therapy (SMD -0.13; 95\% CI $=-0.59$ to $0.34 ; \mathrm{p}=0.59$ ).

Conclusion: Post isometric relaxation and laser therapy have an effect but are not significant in reducing pain in cases of upper trapezius myofascial pain syndrome.

Keywords: Post isometric relaxation, Laser therapy, Myofascial pain syndrome upper trapezius, Meta-Analysis

\section{Correspondence:}

Alifiya Zulfa Indana. Masters Program in Public Health. Universitas Sebelas Maret, Jl. Ir. Sutami 36A, Surakarta 5712, Jawa Tengah, Indonesia. Email: alifiyasindanao@gmail.com Mobile: 082240463478.

\section{Cite this as:}

Indana AZ, Rahardjo SS, Prasetya H (2021). Meta-Analysis the Effectiveness of Isometric Relaxation and Laser Therapy in Reducing Myofascial Pain Syndrome on Musculus Upper Trapezius. J Epidemiol Public Health. 06(02): 245-255. https://doi.org/10.26911/jepublichealth.2021.06.02.11.

cc (i) (-) Journal of Maternal and Child Health is licensed under a Creative Commons Attribution-NonCommercial-ShareAlike 4.o International License.

\section{BACKGROUND}

Myofascial pain syndrome is a chronic pain condition that affects the connective tissue that surrounds muscles (fascia). This pain condition is usually caused by excessive muscle loading and can occur due to continous activities with poor posture and ergonomics (Gerwin, 2014).

Myofascial pain syndrome is a pain syndrome that refers to a form of muscle 
pain that arises from hyperirritable spots located in skeletal muscle links called myofascial trigger points (Desai et al., 2013). Myofascial pain syndrome is common in the upper body, with $84 \%$ of trigger points found in the upper trapezius, scalene, levator scapulae, and infraspinatus muscles. And after several studies have been conducted, the results show that the upper trapezius muscle is the muscle that myofascial trigger point is most often found (Ravichandran et al., 2016). The upper trapezius muscle is also the $34 \%$ that experiences pain the most (Agung et al., 2018).

The incidence of neck pain is estimated within one year ranging from $10.4 \%$ to $23.3 \%$, the prevalence ranges from $0.4 \%$ to $6.8 \%$ (Ravichandran et al., 2016). And the prevalence of myofascial pain syndrome among non-specific neck pain found 93.75\% myofascial trigger point most commonly found in the upper trapezius muscle where the active myofascial trigger point was $82.1 \%$ on the right and $79 \%$ on the left of the upper trapezius muscle (Cerezo-Téllez et al., 2016). The incidence of neck pain in Indonesia in one month is $10 \%$ and in a year it reaches $40 \%$. The prevalence of neck pain in workers reaches $6-67 \%$ and is more experienced by women (Falah, 2018).

The pathophysiology that plays a role in myofascial pain syndrome is the presence of tight and tense muscle fibers and pain when pressure is applied which is also called myofascial trigger point. Myofascial pain syndrome can be local or regional, such as in the neck, shoulders, upper and lower back, usually unilateral or more severe on one side. Muscle pain in myofascial pain syndrome can persist with mild to severe variations, the hallmark of this pain is the presence of trigger points (Atmadja, 2016). There are several physiotherapy treatments that can be given in cases of myofascial pain syndrome such as manual therapy, muscle energy technique (post isometric relaxation), myofascial release, ischemic compression, laser therapy, ultrasound and TENS. Based on research conducted by Ahmed et al. (2020) stated that post isometric relaxation and laser therapy were very effective in reducing pain intensity at the upper trapezius trigger point.

Post isometric relaxation is one of the manual therapy techniques that is quite often done for lengthening shortened muscle fibers, increasing muscle strength and mobilizing joints (Fryer and Pearce, 2013). This technique can also have a great impact on reducing pain and increasing joint range of motion (Ellythy, 2012). The PIR is carried out with the participation of the therapist and patient. While laser therapy has light energy that is transmitted through space as a wave that has a collection of energy called photons (Satria Nugraha et al., 2019). Laser therapy has also been found to be very effective in the management of trigger point pain that triggers cases of myofascial pain syndrome, this laser therapy activates kinetic energy in cells by sending photons which after photons reach cells it will activate the activation process which will cause pain to decrease (Ahmed, 2020).

Based on the number of cases of upper trapezius myofascial pain syndrome that occur and the need for appropriate intervention, the researchers are interested in studying the effect of post isometric relaxation and laser therapy on reducing pain in cases of upper trapezius myofascial pain syndrome. The data obtained will be analyzed using meta-analysis by synthesizing the results of studies conducted to reduce bias. 


\section{SUBJECTS AND METHOD}

\section{Study Design}

This was a systematic review and metaanalysis study design. It was done using the PRISMA flow chart guidelines. Article searches were carried out using journal databases including: PubMed, science Direct, Google Scholar and PEDro articles in the 2010-2020 vulnerable years with the keywords ("MPS Upper Trapezius" OR "Myofascial pain syndrome upper trapezius") AND ("PIR" OR "Post isometric relaxation") AND ("Laser" OR "Laser therapy") AND "randomized controlled trial".

\section{Inclusion Criteria}

This study has inclusion criteria, including: Full paper article with a Randomized Controlled Trial (RCT) study design, The size of the relationship used with Mean SD, Interventions given are Post isometric relaxation and Laser therapy, Research subjects have an age range of 18-65 years and pain measurement using VAS or NRS.

\section{Exclusion Criteria}

This study has exclusion criteria, including: Articles published other than English and Indonesian, studies conducted using an observational design and articles with a history of neck or shoulder trauma such as shoulder fractures, upper thoracic fractures.

\section{Operational Definition of Variables}

The formulation of the research problem was carried out by considering the eligibility criteria defined using PICO, namely, Population: patients with upper trapezius myofascial pain syndrome, Intervention: post isometric relaxation and laser therapy, Comparison: no therapy and Outcome: decreased pain.

Post isometric relaxation is one type of manual therapy from muscle energy technique which is quite often applied to lengthen shortened muscle fibers, increase muscle strength, reduce pain intensity and mobilize joints.

Laser therapy is a clinical application that uses electromagnetic energy with waves of 100- 10,000 nanometers. Light energy is transmitted through space as a wave that has a pool of energy known as photons.

Myofascial pain syndrome is a pain syndrome that refers to a form of muscle pain arising from hyperirritable spots located in skeletal muscle links called myofascial trigger points.

Pain level is a measurement to determine the level of pain as an uncomfortable sensory experience and is associated with tissue damage.

\section{Research Instruments}

The instrument in this study uses a Visual Analog Scale (VAS) or Numeric rate scale (NRS) as a pain measurement tool in patients with upper trapezius Myofascial pain syndrome.

\section{Data Analysis}

Data analysis in this study was carried out using the Review Manager application (RevMan 5.3). Data were analyzed based on variations between studies by determining the use of random effects analysis models. This study used $\mathrm{I}^{2}$ to quantify the dispersion. The results of the data analysis are in the form of the effect size value of the heterogeneity of the study which later the results of the analyzed data are interpreted in the form of forest plots and funnel plots.

\section{RESULTS}

Research from the primary study related to the effect of post isometric relaxation and laser therapy on pain reduction in cases of upper trapezius myofascial pain syndrome contained 16 articles with a total sample of 646 participants, 336 participants for intervention and 325 participants for comparison. Articles were obtained from 3 continents, namely, 9 studies from the Asian 
Indana et al./ Isometric Relaxation and Laser Therapy in Reducing Myofascial Pain Syndrome

continent, 5 from the European continent, 1 from the Australian continent. Each study had a sample of less than 100 participants. The outcome for some articles is that there is a decrease in pain levels after being given post isometric relaxation and laser therapy interventions.

The article search was carried out using a database based on the PRISMA flow diagram, which can be seen in Figure 1. The study quality assessment was carried out qualitatively and quantitatively. Assessment of research quality using the Critical Appraisal Skills Program (CASP) can be seen in Table 1. Each of the 11 questions was answered with the answer choices: Yes, No and Unclear. After assessing the quality of the study, a total of 16 articles included in the quantitative synthesis process of the meta-analysis were analyzed using RevMan $5 \cdot 3$

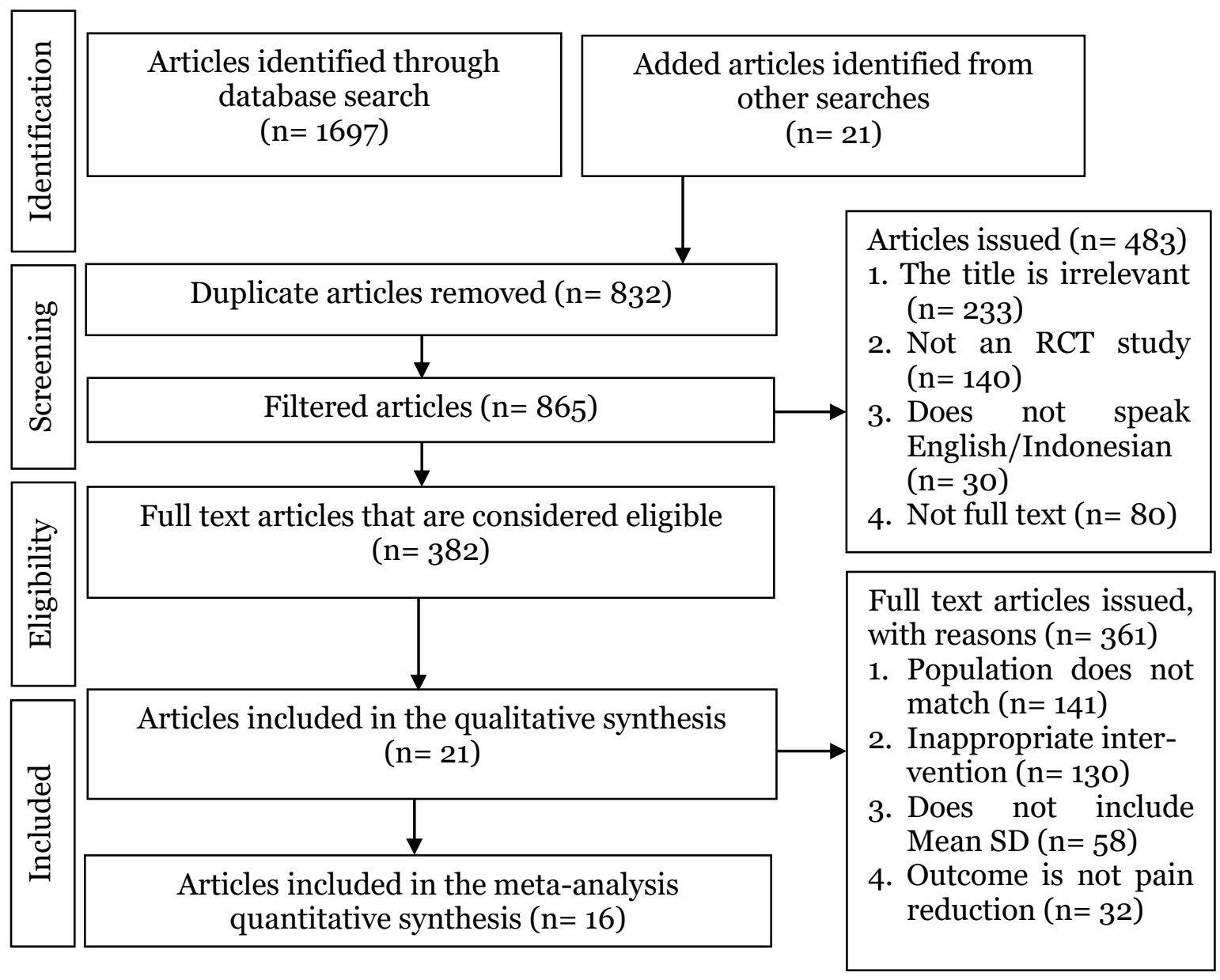

Figure 1. PRISMA flow diagram 
Indana et al./ Isometric Relaxation and Laser Therapy in Reducing Myofascial Pain Syndrome

Table 1. Research Quality Assessment

\begin{tabular}{|c|c|c|c|c|c|c|c|c|c|c|c|}
\hline Author(s) & $\mathbf{1}$ & 2 & 3 & 4 & 5 & 6 & 7 & 8 & 9 & 10 & $\mathbf{1 1}$ \\
\hline Ahmed et al., (2020) & Yes & Yes & Yes & Yes & Yes & Yes & Yes & Yes & Yes & Yes & Yes \\
\hline $\begin{array}{l}\text { Alghadir et al., } \\
\text { (2020) }\end{array}$ & Yes & Yes & Yes & Yes & Yes & Yes & No & Yes & Yes & Yes & Yes \\
\hline Junaid et al., (2020) & Yes & Yes & Yes & Yes & Yes & Yes & Yes & Yes & Yes & Yes & $\begin{array}{l}\text { Not } \\
\text { Clear }\end{array}$ \\
\hline $\begin{array}{l}\text { KashYesp et al., } \\
(\mathbf{2 0 1 8 )}\end{array}$ & Yes & Yes & Yes & Yes & Yes & Yes & Yes & No & Yes & Yes & $\begin{array}{l}\text { Not } \\
\text { Clear }\end{array}$ \\
\hline Kumar et al., (2015) & Yes & Yes & Yes & Yes & Yes & Yes & Yes & Yes & Yes & Yes & $\begin{array}{l}\text { Not } \\
\text { Clear }\end{array}$ \\
\hline Phadke et al., (2016) & Yes & Yes & Yes & Yes & Yes & Yes & Yes & Yes & Yes & Yes & Yes \\
\hline Sadria et al., (2016) & Yes & Yes & Yes & Yes & Yes & Yes & Yes & Yes & Yes & Yes & Yes \\
\hline $\begin{array}{l}\text { Wendt \& Waszak } \\
(2020)\end{array}$ & Yes & Yes & Yes & Yes & Yes & Yes & Yes & Yes & No & Yes & $\begin{array}{l}\text { Not } \\
\text { Clear }\end{array}$ \\
\hline $\begin{array}{l}\text { Yegenehlari et al., } \\
\text { (2016) }\end{array}$ & Yes & Yes & Yes & Yes & Yes & Yes & Yes & Yes & Yes & Yes & $\begin{array}{l}\text { Not } \\
\text { Clear }\end{array}$ \\
\hline Dundar et al., (2014) & Yes & Yes & Yes & Yes & Yes & Yes & Yes & Yes & Yes & Yes & Yes \\
\hline $\begin{array}{l}\text { PriYes Kannan } \\
\text { (2012) }\end{array}$ & Yes & Yes & Yes & Yes & Yes & Yes & Yes & Yes & Yes & Yes & $\begin{array}{l}\text { Not } \\
\text { Clear }\end{array}$ \\
\hline Kiraly et al., (20 & Yes & Yes & Yes & Yes & Yes & Yes & No & Yes & Yes & Yes & Yes \\
\hline Manca et al., (2014) & Yes & Yes & Yes & Yes & Yes & Yes & Yes & Yes & Yes & Yes & Yes \\
\hline Sumen et al., (2015) & Yes & Yes & Yes & Yes & Yes & Yes & Yes & Yes & Yes & Yes & $\begin{array}{l}\text { Not } \\
\text { Clear }\end{array}$ \\
\hline.,$(2016)$ & Yes & Yes & Yes & Yes & Yes & Yes & Yes & Yes & Yes & Yes & Yes \\
\hline Khiavi et al., (2020) & Yes & Yes & Yes & Yes & Yes & Yes & Yes & No & Yes & Yes & $\begin{array}{l}\text { Not } \\
\text { Clear }\end{array}$ \\
\hline
\end{tabular}

1. The effect of post isometric relaxation on pain reduction in upper trapezius myofascial pain syndrome cases

a. Forest plot post isometric relaxation on pain reduction in upper trapezius myofascial pain syndrome cases

Interpretation of the results of the metaanalysis process can be seen through the forest plot. Figure 2 shows as many as 9 articles reporting that post isometric relaxation can reduce pain in cases of upper trapezius myofascial pain syndrome compared to other interventions or no intervention. Meanwhile, there was high heterogeneity between experiments $\left(I^{2}=84 \%\right.$ : $p$ $<0.001)$. Thus, the Random Effect Model is used to analyze the data in the forest plot. Post isometric relaxation can reduce pain in patients with upper trapezius Myofascial pain syndrome by 0.18 times compared to other interventions or no intervention, but statistically not significant (SMD 0.18; 95\% $\mathrm{CI}=-0.36$ to $0.72 ; \mathrm{p}=0.51)$.

b. Funnel plot Post isometric relaxation on pain reduction in upper trapezius myofascial pain syndrome cases

A funnel plot is a plot that represents the approximate size of the effect of each study on the estimate of its accuracy, which is usually the standard error. Figure 3 funnel plot of Post isometric relaxation on pain reduction in cases of upper trapezius myofascial pain syndrome, showing that there is a publication bias that is marked by asymmetrical plots. 
Indana et al./ Isometric Relaxation and Laser Therapy in Reducing Myofascial Pain Syndrome

2. The effect of laser therapy on pain reduction in cases of upper trapezius myofascial pain syndrome

a. Forest Plot Laser therapy for pain reduction in cases of myofascial pain syndrome trapezius

Interpretation of the results of the metaanalysis process can be seen through the forest plot. Figure 4 shows as many as 8 articles reporting that laser therapy can reduce pain in cases of upper trapezius myofascial pain syndrome compared to other interventions or no intervention. Meanwhile, there was high heterogeneity between experiments $\left(\mathrm{I}^{2}=73 \%\right.$; $\left.\mathrm{p}<0.001\right)$. Thus, the Random Effect Model is used to analyze the data in the forest plot. Performed Yesk Laser therapy can reduce pain in patients with Myofascial pain syndrome upper trapezius as much as Yesk -o.13 times compared to other interventions or no intervention, but statistically not significant (SMD -0.13; 95\% CI $=-0.59$ to $0.34 ; \mathrm{p}=0.59$ ).

b. Funnel Plot Laser therapy for pain reduction in cases of upper trapezius myofascial pain syndrome

Figure 5 funnel plot of Laser therapy on pain reduction in cases of upper trapezius myofascial pain syndrome, shows that there is publication bias which is characterized by asymmetrical plots.

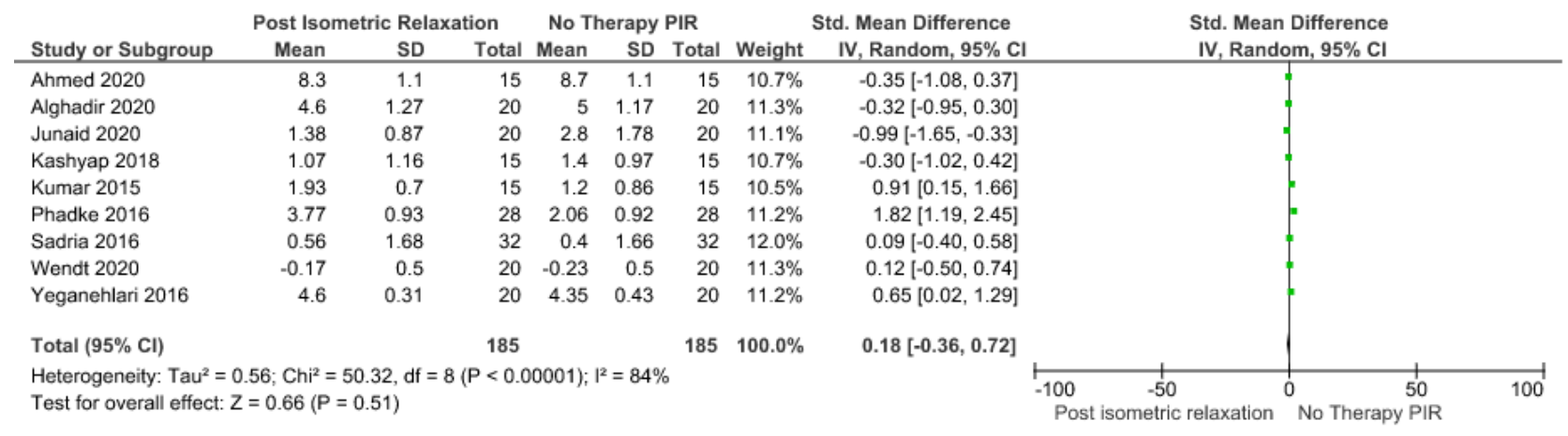

Figure 2. Forest plot Post isometric relaxation on pain reduction in upper trapezius myofascial pain syndrome cases

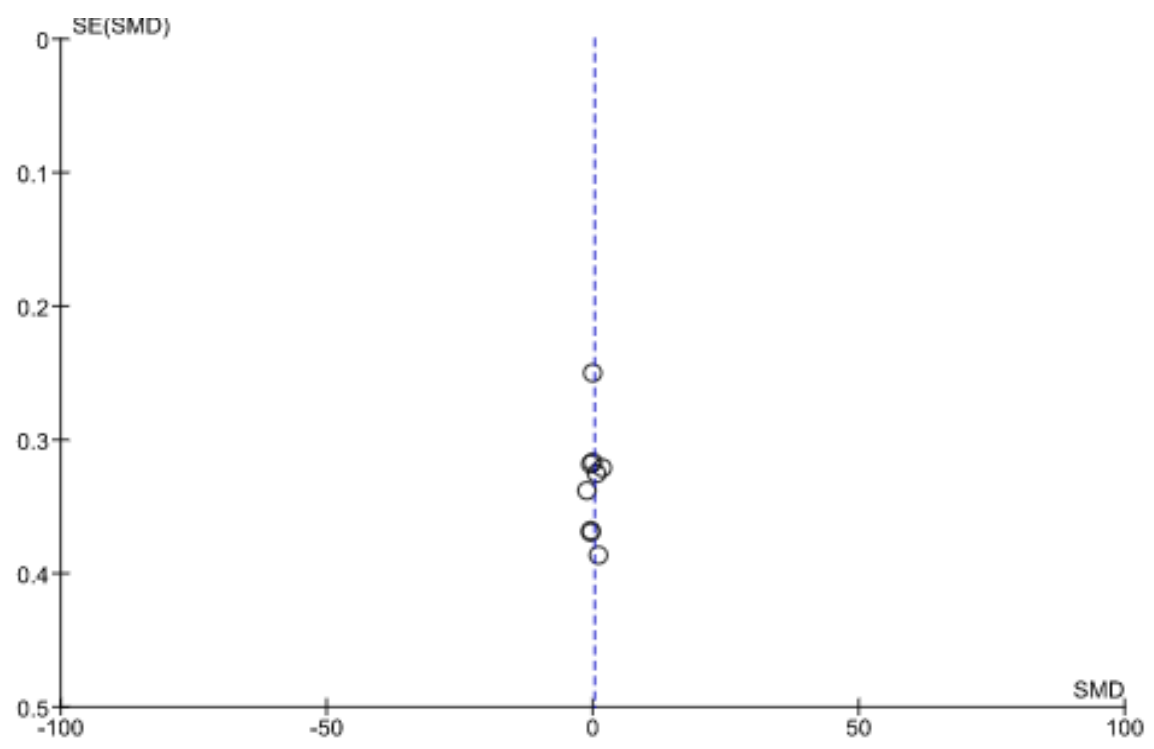

Figure 3. Funnel plot of Post isometric relaxation on pain reduction in upper trapezius myofascial pain syndrome cases 
Indana et al./ Isometric Relaxation and Laser Therapy in Reducing Myofascial Pain Syndrome

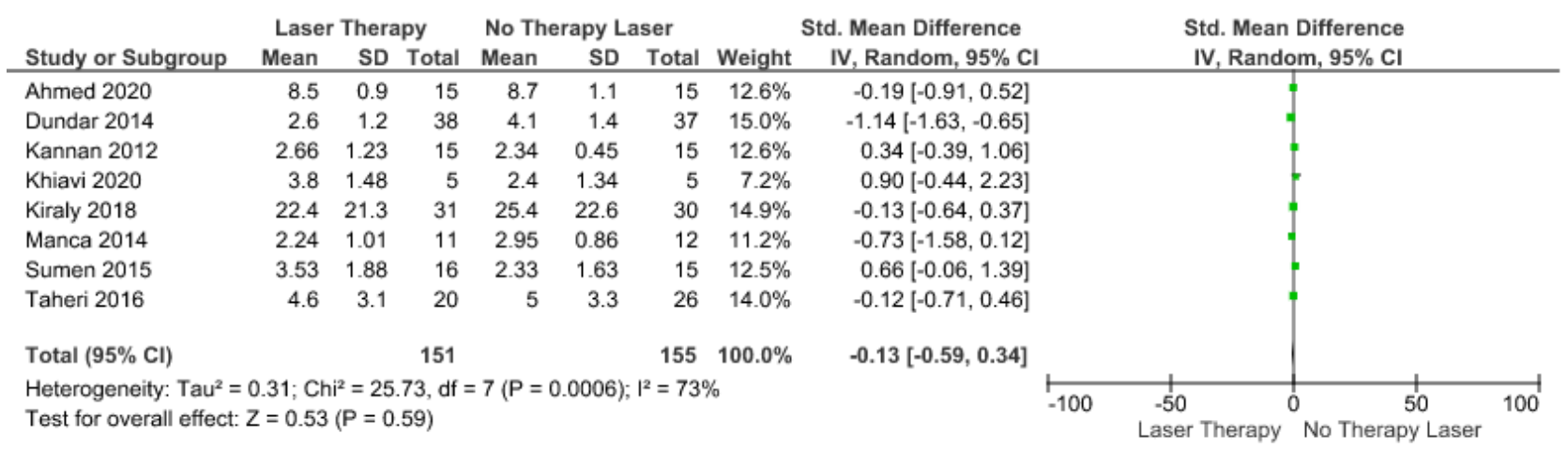

Figure 4. Forest plot Laser therapy for pain reduction in cases of upper trapezius myofascial pain syndrome

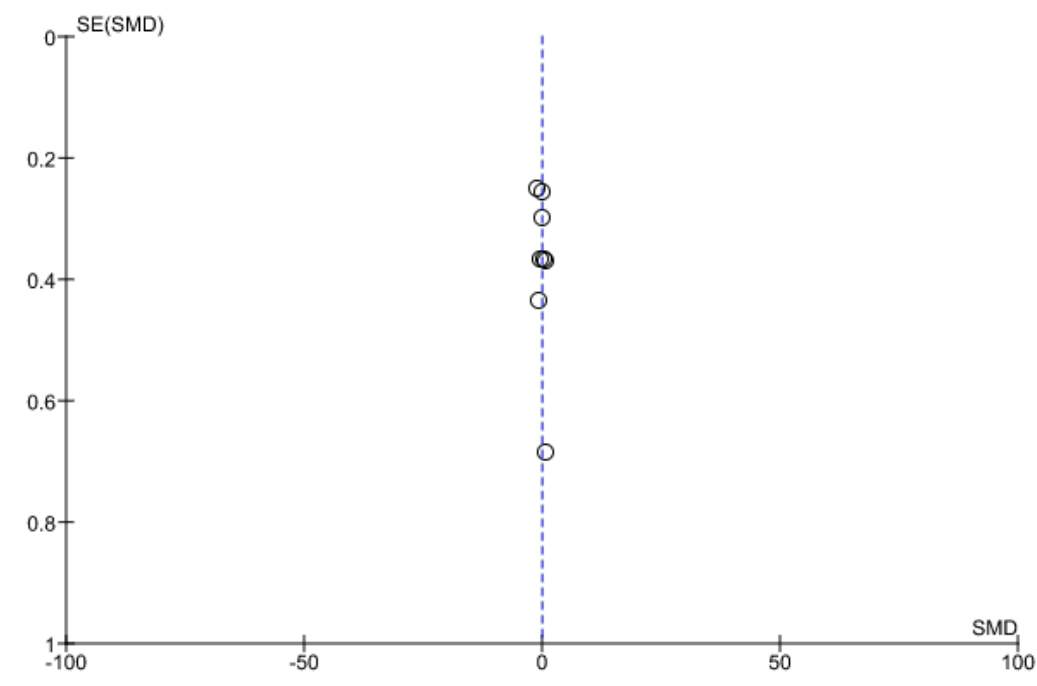

\section{Figure 5. Funnel plot Laser therapy for pain reduction in upper trapezius myofascial pain syndrome cases}

Pain is the symptom that most patients complain about when taking treatment. Pain is defined as an uncomfortable sensory experience associated with tissue damage. With this pain, it is intended that a person becomes more sensitive to stimuli so as to prevent further damage (Wilson, 2014). Neck pain is one of the most common musculoskeletal problems, about two thirds of the general population experience neck pain and the highest prevalence is in productive ages (Binder, 2007).

Myofascial trigger points are often found in the neck and back, such as in the trapezius muscle. It is here this muscle is a muscle consisting of muscle fibers that are long and wide. The trapezius is the muscle that allows and supports the spine to stay upright. The coordination of this muscle group results in neck extension movements which if used for a long time and in a static position will cause muscle stiffness so that there is pain and limitation of motion (Haddad et al., 2012).

There are many interventions that can be given in cases of upper trapezius myofascial pain syndrome such as post isometric relaxation and laser therapy. The two interventions are manual therapy techniques and electrotherapy that are quite 
often used in pain management in musculoskeletal cases. Post-isometric relaxation is a method of muscle energy technique that relies on the provision of isometric contractions and muscle relaxation to reduce pain, stretch muscles and fascia, reduce tone and mobilize joints (Fryer \& Pearce, 2013). The existence of stretching in this technique aims to lengthen the Yesng muscle which is shortened and hypomobile (Mahajan et al., 2012). Giving stretching in musculoskeletal cases provides many benefits such as decreasing pain, increasing flexibility and increasing range of motion (Chaitow, 2013).

Laser therapy itself is an intervention that relies on electromagnetic energy with waves of 100-10,000 nanometers. Light energy is transmitted through space as a wave that has a collection of energy called photons (Satria Nugraha et al., 2019). The classification of laser therapy is low power laser and high-power laser. Low power lasers are known as "cold lasers" and are usually used for tissue repair and pain relief. Laser light has the properties of monomanicity (single wavelength), collimation (one-way travel without divergence) and coherence (waves coalescing in phase). These properties allow laser light to penetrate the skin surface non-invasively. Laser therapy is also athermic or without heat transfer $\left(<0.65^{\circ} \mathrm{C}\right)$ so that photons can go directly to target cells (Ahmed, 2020).

The results of this study are in line with Ahmed et al., (2020) which stated that post-isometric relaxation and laser therapy interventions were effective in reducing pain pressure thresholds and pain intensity at the upper trapezius muscle trigger point. The effectiveness of these two interventions is mainly due to the variation in their effects (Wseem et al., 2010). Post isometric relaxation is carried out with the participation of the therapist and patient so that management is more optimal and effective in reducing pain which is triggered by several therapeutic effects such as muscle lengthening, strengthening muscles, helping lymphatic or venous pumps to increase fluid or blood drainage and increasing the range of motion of the joints. limited (Nagrwal, 2010).

This statement is also in line with the results of Yesng's study by Kumar et al., 2014 where it was concluded that postisometric relaxation was far superior and effective compared to other interventions in pain management in cases of upper trapezius myofascial pain syndrome. This is because MET (muscle energy technique) is a manual therapy technique that is highly recommended in reducing trigger point pain (Robert-Shawe, 2007). And PIR is one method of MET that focuses on achieving tone release, namely by inhibiting the muscle before stretching (Chaitow, 2013). The PIR technique involves an isometric contraction of the muscle that will affect the Golgi tendon and provide a relaxing effect after an isometric contraction (Nagrale et al., 2010).

This study is also in line with research conducted by Chang et al., (2014) related to the effect of laser therapy on reducing pain in cases of myofascial pain syndrome. This study states that low level laser therapy applied to the upper trapezius trigger point area is very significant in alleviating pain in myofascial pain syndrome cases and is effective in increasing the range of motion of the joints. This study uses low-level laser therapy of $810 \mathrm{~nm}$ and $150 \mathrm{~mW}$ where these waves are very effective in managing pain at trigger points that cause myofascial pain syndrome (Chow et al., 2006).

Kingsley (2014) also stated that giving low-level laser therapy is quite useful and effective in reducing chronic pain such as myofascial pain syndrome. And this study 
is also in line with Agung et al., (2018) which concluded that giving low-level laser therapy is more effective in reducing pain intensity in cases of upper trapezius myofascial pain syndrome than dry needling intervention. This conclusion is supported by Gerber et al., (2018) that low level laser therapy can increase range of motion (ROM) and reduce trigger point pain due to increased blood flow and oxygenation due to increased microcirculation of pain trigger points.

This study is not significant and is in line with Lamba (2011), ThiYesgarajan \& Milton, (2012) because these studies concluded that post isometric relaxation is not effective if given without a combination of ischemic compression and TENS in reducing pain in upper trapezius myofascial pain syndrome. Giving PIR with a combination of ischemic compression or TENS is considered more significant in reducing pain in cases of upper trapezius MPS. This is because the presence of Yesng short wave diathermy means Yesng's deep warming modality of physical therapy. It has a significant effect on relieving pain and increasing temperature in the tissues as heat causes increased arteriolar and capillary dilatation followed by increased blood flow to the area.

The results of Milanesi's study, (2020) are not in line with this study because the administration of low-level laser therapy is indeed effective in improving quality of life but is not efficient in reducing pain in cases of upper trapezius myofascial pain. This statement is also reinforced by Chen and Nizar (2011) that the administration of low-level laser therapy is more effective in improving the functional condition of patients. This is because low level laser therapy is a new method used and there is still controversy about its therapeutic effect. The energy density and optical properties of the tissue are also considered as important factors affecting the effectiveness of low-level laser therapy such as consideration of wavelength and therapy sessions.

\section{AUTHOR CONTRIBUTION}

Alifiya Zulfa Indana is the main researcher Yesng selects the topic, searches and collects research data. Setyo Sri Rahardjo and Hanung Prasetya analyzed data and reviewed research documents.

\section{FUNDING AND SPONSORSHIP}

This study is self funded.

CONFLICT OF INTEREST

There is no conflict of interest in this study.

\section{ACKNOWLEGMENT}

The researcher would like to thank all those who have helped in the preparation of this article and also thank the database providers PubMed, Science Direct, Google Scholar and PEDro.

\section{REFERENCES}

Agung I, Murdana N, Purba H, Fuady A (2018). Low-level laser therapy and dry needling for myofascial pain syndrome of the upper trapezius muscle: An interventional study. J Phys Conf Ser. 1073(6). https://doi.org/10.1088/1742-6596/1073/6/062045.

Ahmed (2020). Effect of post-isometric relaxation and laser on upper trapezius trigger point pain in patients with mechanical neck pain. Niger $J$ Clin Pract. 23(12): 1660-1666 https://doi.org/10.4103/njcp.njcp.

Atmadja S (2016). Sindrom nyeri myofasial. Cermin dunia kedokteran. 43(3): 176179.http://www.cdkjournal.com/index.php/CDK/article/view/29.

Binder AI (2007). Cervical spondylosis and 
Indana et al./ Isometric Relaxation and Laser Therapy in Reducing Myofascial Pain Syndrome

neck pain. BMJ. 334(7592), 527-531. https://doi.org/10.1136/bmj.39127.60 8299.80.

Cerezo-Téllez E, Torres-Lacomba M, Mayoral-del Moral O, Sánchez-Sánchez, B Dommerholt J, Gutiérrez-Ortega C. (2016). Prevalence of myofascial pain syndrome in chronic non-specific neck pain: A population based cross sectional descriptive study. Pain Med, 17(12): 2369-2377. https://doi.org/$10.1093 / \mathrm{pm} / \mathrm{pnw} 114$.

Chaitow L (2013). Muscle energy techniques. Elsevier Health Sciences https://doi.org/10.1093/pm/pnw114

Chang WD, Wu JH, Wang HJ, Jiang JA (2014). Therapeutic outcomes of lowlevel laser therapy for closed bone fracture in the human wrist and hand. Photomed Laser Surg. 32(4), 212218. https://doi.org/10.1089/pho.2012.3398.

Chen CK, Nizar AJ (2011). Myofascial pain syndrome in chronic back pain patients. Korean J Pain. 24(2), 100-104. https://doi.org/10.3344/kjp.2011.24. 2.100 .

Chow RT, Heller GZ, Barnsley L (2006). The effect of $300 \mathrm{~mW}, 830 \mathrm{~nm}$ laser on chronic neck pain: A double-blind, randomized, placebo-controlled study. J Pain. 124(1-2): 201-210. https://doi.org/10.1016/j.pain.2006.05.018.

Desai MJ, Saini V, Saini S (2013). Myofascial pain syndrome: a treatment review. Pain Ther. 2(1): 21-36. https://doi.org/10.1007/s40122-013ooo6-y.

Dheeraj Lamba SP. (2011). Effect of post isometric relaxation on pain intensity, functional disability and cervical range of motion in myofacial pain of upper trapezius. Indian $\mathrm{J}$ Physiother Occup Ther. 5(1), 56-59. http://www.- ijpot.com/

Ellythy MA (2012). Efficacy of muscle energy technique versus strain counter strain on low back dysfunction. Phys Ther. 17(2), 29-35. http://erepository.cu.edu.eg.

Falah (2018). Pengaruh penambahan stretching exercises pada kompres panas terhadap penurunan nyeri pada neck pain syndrome (The effect of adding stretching exercises to hot compresses on reducing pain in neck pain syndrome). Skripsi. http://eprints.ums.ac.id.

Fryer G, Pearce AJ (2013). The effect of muscle energy technique on corticospinal and spinal reflex excitability in asymptomatic participants. J Bodyw Mov Ther. 17(4): 440-447. https://doi.org/10.1016/j.jbmt.2013.05.006.

Gerber S, Fesel J, Doser M, Comparat D (2018). Photodetachment and doppler laser cooling of anionic molecules. New J Phys. 20(2). https://doi.org/10.1088/1367-2630/aaa951.

Gerwin RD (2014). Diagnosis of myofascial pain syndrome. Phys Med Rehabil Clin N Am. 25(2): 341-355. https://doi.org/10.1016/j.pmr.2014.01.011.

Haddad O, Sanjari MA, Amirfazli A, Narimani R, Parnianpour M (2012). Trapezius muscle activity in using ordinary and ergonomically designed dentistry chairs. Int $\mathrm{J}$ Occup Environ Med, 3(2): 76-83. https://theijoem.com/ijoem/index.php/ijoem/article/view/138.

J. Derek Kingsley, Timothy D, Reed M. (2014). Low-level laser therapy as a treatment for chronic pain. Front. Physiol, 5(306), 1-3. doi: 10.3389/fphys.2014.00306.

Mahajan R, Kataria C, Bansal K (2012). Comparative effectiveness of muscle energy technique and static stretching 
Indana et al./ Isometric Relaxation and Laser Therapy in Reducing Myofascial Pain Syndrome

for treatment of subacute mechanical neck pain. Int $J$ Health Rehabil Sci. 1(1): 16. https://doi.org/10.5455/ijhrs.00000004.

Maracci LM, Stasiak G, de Oliveira Chami V, Franciscatto G J, Milanesi J, Figueiró C, Marquezan M (2020). Treatment of myofascial pain with a rapid laser therapy protocol compared to occlusal splint: A double-blind, randomized clinical trial. Cranio. 1-7. https://doi.org/10.1080/o8869634.2020.1773661.

Nagarwal AK, Zutshi K, Ram CS, Zafar R (2010). Improvement of hamstring flexibility: a comparison between two pnf stretching techniques. I Int $\mathrm{J}$ Sports Eng. 04(01): 1750-9823. https://doi.org/10.1.1.1072.3355.

Nagrale AV, Glynn P, Joshi A, Ramteke G. (2010). The efficacy of an integrated neuromuscular inhibition technique on upper trapezius trigger points in subjects with non-specific neck pain: A randomized controlled trial. J Man Manip Ther. 18(1): 37-43. https://doi.org/10.1179/106698110X1259577 0849605 .

Ravichandran SP, Shah PB, LakshminaraYesnan K (2016). Musculoskeletal problems among workers in a garment industry, at Tirupur, Tamil Nadu. Indian $\mathrm{J}$ Community Health. 28(o3). http://www.iapsmupuk.org/.../pdf_439.

Robertshawe P (2007). Niel-Asher S. The concise book of trigger points. $\mathrm{J}$ Australian Traditional-Med Soc. 13(2): 114. https://link.gale.com/apps/doc/A165939843/AONE?u=an- on 5243cdeb\&sid=bookmark-AONE\&xid=d18115bo.

SSatria Nugraha MH, Wahyuni N, Sita Saraswati PA (2019). Efektivitas Low power laser terapi dan proprioceptif neuromuscular facilitation pada ulkus diabetikum derajat 2 (The effectiveness of low power laser therapy and proprioceptive neuromuscular facilitation on grade 2 . diabetic ulcers). J Sport Health Sci. 43-50. https://doi.org/10.24843/spj.2019.v07.io2.po6.

ThiYesgarajan S, Milton JA (2012). A comparative study between the efficacies of post isometric relaxation versus post isometric relaxation with TENS on upper trapezius myofascial pain syndrome. Indian J Physiother Occup Ther. 6(1): 196-199. https://www.researchgate.net/profile/Lori-MariaWalton-2/publication/256018953_Socio-Economic_Barriers_to_Maternal_Health_in_Bangladeshi_Wom en/links/542d88920cf29bbc126d39e 4/Socio-Economic-Barriers-to-Maternal-Health-in-Bangladeshi-Women.pdf $\#$ page $=\mathbf{2 0 0}$.

Waseem M, Nuhmani S, Ram C (2010). Comparative effectiveness of static stretching and muscle energy technique on hamstring flexibility in normal Indian collegiate males. Indian J Physiother Occup Ther, 4(3): 91-94. http://www.ijpot.com/scripts/IJPOT\%2OJuly-sept\%202010.

Wilson M (2014). Integrating the concept of pain interference into pain management. Pain Manag Nurs, 15(2): 499505. https://doi.org/10.1016/j.pmn.2011.06.004. 